\title{
THE ATMOSPHERIC $\delta^{13} \mathrm{C}$ RECORD AS DERIVED FROM 56 PINYON TREES AT 14 SITES IN THE SOUTHWESTERN UNITED STATES
}

\author{
$S$ W LEAVITT \\ Department of Geology, University of Wisconsin-Parkside \\ Kenosha, Wisconsin 53141-2000 \\ and \\ AUSTIN LONG \\ Department of Geosciences, University of Arizona, Tucson, Arizona 85721

\begin{abstract}
We have developed a master $\delta^{13} \mathrm{C}$ chronology from 14 pinyon pine sites in 6 states of the southwestern U S. Two of the individual isotopic chronologies, reported here for the first time, and 10 of those previously reported (Leavitt \& Long, 1986; 1988) are from sites where cores from 4 trees were pooled prior to analysis, and the other 2 are merged from groups of 4 single-tree chronologies (sites) developed in an earlier phase of research (Leavitt \& Long, 1985). Regressions of first differences of ring-width indices and $\delta^{13} \mathrm{C}$ values from each site were used to "correct" individual $\delta^{13} \mathrm{C}$ chronologies for climate effects which appear primarily related to high-frequency $\delta^{13} \mathrm{C}$ fluctuations, many of which are common among sites. These climate-corrected chronologies were normalized as deviations from their respective $1800-1849$ $\delta^{13} \mathrm{C}$ means, and these normalized chronologies were averaged into the master. The overall $\delta^{13} \mathrm{C}$ drop from 1600 to the present is ca $1.2-1.4 \%$, consistent with recent ice-core data showing a drop of $1.14 \pm 0.15 \%$ from 1740 to present (Friedli et al, 1986). However, the $\delta^{13} \mathrm{C}$ decline in the late 19th and early 20th centuries is greater in the pinyon chronology than that of the ice cores, thus supporting a greater biospheric $\mathrm{CO}_{2}$ input to the atmosphere than that indicated in the ice-core data.
\end{abstract}

\section{INTRODUCTION}

Attempts have been made to reconstruct concentrations of atmospheric $\mathrm{CO}_{2}$ concentrations and $\delta^{13} \mathrm{C}$ of $\mathrm{CO}_{2}$ in order to better understand the carbon cycle and how human activities may be influencing it. For over a decade, tree rings have been used in attempts to reconstruct $\delta^{13} \mathrm{C}$ atmospheric $\mathrm{CO}_{2}$ (eg, Peng et al, 1983; Stuiver, Burk \& Quay, 1984). More recently, measurements of $\mathrm{CO}_{2}$ concentrations and $\delta^{13} \mathrm{C}$ in air bubbles trapped in ice cores (Friedli et al, 1986) have provided a more direct measurement, without the physiological complications with which the tree-ring reconstructions must contend.

In this paper, we present the last two tree-ring $\delta^{13} \mathrm{C}$ chronologies from southwestern pinyon pine which have been carefully selected, sampled, dated, analyzed and then corrected for climate influences. The overall strategy was to minimize physiological effects and maximize the potential that the chronologies represent the atmosphere. These were merged with 12 other $\delta^{13} \mathrm{C}$ chronologies for the final master pinyon chronology which is compared to ice-core and atmospheric $\delta^{13} \mathrm{C}$ measurements. 


\section{METHODS}

A number of pinyon individuals from the Gate Canyon, Utah (15 trees), and Lamoille, Nevada (8 trees), sites were cored (4 orthogonal cores per tree) in July 1986 (Table 1). Following dendrochronologic dating, cores from 4 of the "best" were pooled together in pentad groups $(\ldots, 1800-04$, $1805-09, \ldots)$, ground to 20 mesh, and then reduced to (holo-)cellulose by sodium chlorite oxidation. The methods of selecting the best trees, sample preparation and combustion to $\mathrm{CO}_{2}$ are described in detail in Leavitt and Long $(1986 ; 1988)$. The $\mathrm{CO}_{2}$ thus obtained was analyzed mass-spectrometrically with ${ }^{13} \mathrm{C} /{ }^{12} \mathrm{C}$ ratios expressed as $\delta^{13} \mathrm{C}$. Overall precision for cellulose preparation, sample combustion and isotopic analysis is estimated to be \pm $0.1 \%$. Detailed characteristics of the 12 other pinyon sites and chronologies are presented in Leavitt and Long (1988).

TABLE 1

Summary of site and sampling information

GATE CANYON: $P$ edulis; $\left(39^{\circ} 52^{\prime} 40^{\prime \prime} \mathrm{N}, 110^{\circ} 13^{\prime} 15^{\prime \prime} \mathrm{W}\right)$; elev $2220 \mathrm{~m} ; \delta^{13} \mathrm{C}$ chronology 1580-1985

\begin{tabular}{rlc}
\hline Pooled trees \& contribution of each core $(\mathrm{N}, \mathrm{S}, \mathrm{E}, \mathrm{W})$ & $\begin{array}{c}\text { Earliest dated } \\
\text { year of tree }\end{array}$ \\
\hline$\# 1$ & $1725-1985(\mathrm{~N}, \mathrm{~S}, \mathrm{E}, \mathrm{W})$ & 1682 \\
3 & $1690-1985(\mathrm{~N}, \mathrm{~S}, \mathrm{E}, \mathrm{W})$ & 1648 \\
8 & $1620-1985(\mathrm{~N}, \mathrm{~S}, \mathrm{E}, \mathrm{W})$ & 1581 \\
10 & $1580-1985(\mathrm{~N}, \mathrm{~S}, \mathrm{~W}), 1580-1938(\mathrm{E})$ & 1536 \\
\hline
\end{tabular}

LAMOILLE: $P$ edulis; $\left(40^{\circ} 41^{\prime} 31^{\prime \prime} \mathrm{N}, 115^{\circ} 27^{\prime} 57^{\prime \prime} \mathrm{W}\right)$; elev $2130 \mathrm{~m} ; \delta^{13} \mathrm{C}$ chronology $1620-1985$

\begin{tabular}{rlc}
\hline Pooled trees \& contribution of each core (N,S,E,W) & $\begin{array}{c}\text { Earliest dated } \\
\text { year of tree }\end{array}$ \\
\hline$\# 1$ & $1740-1985(\mathrm{~N})$ 1660-1985 (S,E,W) & 1624 \\
2 & $1620-1985(\mathrm{~N}, \mathrm{~S}, \mathrm{E}, \mathrm{W})$ & 1543 \\
3 & $1690-1985(\mathrm{~N}, \mathrm{E}, \mathrm{W}), 1735-1985(\mathrm{~S})$ & 1654 \\
8 & $1835-1985(\mathrm{~N}, \mathrm{~S}, \mathrm{E}, \mathrm{W})$ & 1771 \\
\hline
\end{tabular}

\section{RESULTS AND DISCUSSION}

The $\delta^{13} \mathrm{C}$ chronologies from Gate Canyon and Lamoille are depicted in Figure $1(\mathrm{a}, \mathrm{b})$. Both curves show decreasing $\delta^{13} \mathrm{C}$ trends, especially after 1800 , although the overall decrease at Gate Canyon is somewhat greater than at Lamoille. Rather than simply average these with the 12 other southwestern pinyon chronologies also sampled with 4 trees per site (Leavitt \& Long, 1988), we first attempted a correction for climate via tree-ring width indices, which are a proxy measure for climate in the American West (Fritts, 1976). Our previous experience with pinyon (Leavitt \& Long, 1985; 


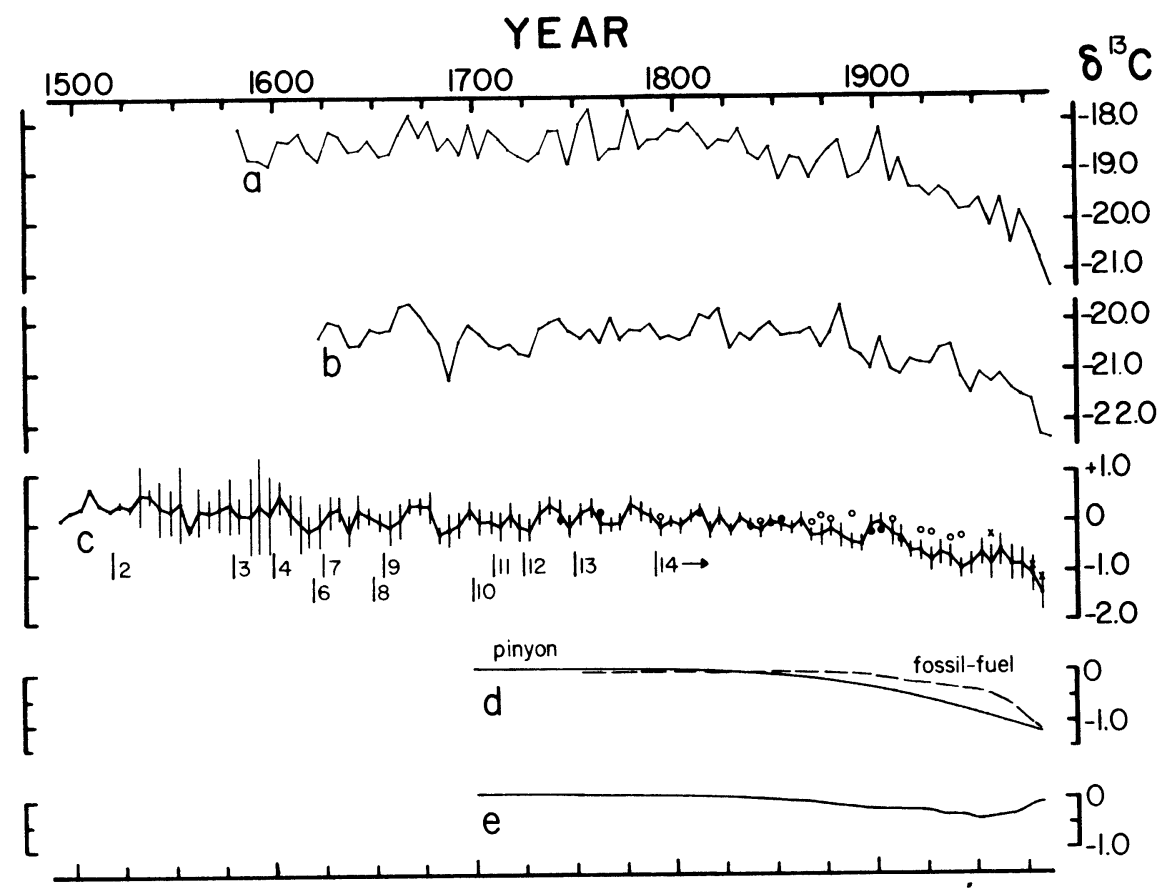

Fig 1. Original $\delta^{13} \mathrm{C}$ chronologies from Gate Canyon (a) and Lamoille (b); master 14-site, climate-corrected $\delta^{13} \mathrm{C}$ chronology (normalized to $1800-1849$ means prior to averaging). Vertical bars $= \pm 2 \sigma ; o=$ ice core results, $\mathrm{x}=$ atmospheric measurements (summarized in Friedli et al, 1986) (c); smoothed tree-ring $\delta^{13} \mathrm{C}$ curve from $\mathrm{c}$ and fossil-fuel $\delta^{13} \mathrm{C}$ effect on atmosphere from Peng et al (1983) (d); residual of 2 curves in d which may represent the biospheric influence on atmospheric $\mathrm{CO}_{2}(\mathrm{e})$.

1986) was that the high-frequency fluctuations on the long-term trends are strongly correlated to ring-width indices (inversely). This inverse correlation, particularly strong with first differences of $\delta^{13} \mathrm{C}$ and indices, is the basis for a correction in which the regression equations for $\Delta \delta^{13} \mathrm{C} v s \Delta$ ring-width index are used to calculate a $\delta^{13} \mathrm{C}$ adjustment for each pentad scaled to the difference between the ring-width index and 1.00. The $\Delta \delta^{13} \mathrm{C} v s \quad \Delta$ index regressions for the other 12 pinyon chronologies and for Gate Canyon were all significant at $\mathrm{P}<.01$, even when degrees of freedom were reduced for effects of autocorrelation (Ezekiel \& Fox, 1959). The regression for Lamoille, however, was only significant at $\mathrm{P}<.1$, and furthermore, the correlation was the only positive one of the 14 . Nevertheless, we used all these regressions to correct the $\delta^{13} \mathrm{C}$ chronologies of each site for climate effects. After correction, each pentad was normalized as differences with its respective $1800-1849$ mean, a period common to all sites and early in the Industrial Revolution. 
The resulting 14 normalized curves were averaged to produce the mean curve in Figure 1c. The vertical bars represent $\pm 2 \sigma$ of the mean, and are smallest between 1750 and 1900 but larger in the post-1900 period, perhaps related to increasing anthropogenic influences. Between 1600 and 1800 , the trend is flat, although prior to 1600 it is also flat with a somewhat higher $\delta^{13} \mathrm{C}$ value. In the latter case, however, standard errors are much greater and trees fewer. In spite of our corrections for climate, high-frequency fluctuations remain in the master chronology, although now they are highly damped relative to their amplitues in the original chronologies such as in Figure 1a,b.

This final pinyon chronology may be compared to other $\delta^{13} \mathrm{C}$ results. First, there are the $\delta^{13} \mathrm{C}$ values of $\mathrm{CO}_{2}$ from ice cores (Friedli et al, 1986; Siegenthaler \& Oeschger, 1987) and direct atmospheric measurements (Keeling, Mook \& Tans, 1979; Keeling, Bacastow \& Tans, 1980; Mook et al, 1983) which are plotted as o's and x's, respectively, in Figure 1c after first normalizing them as deviations from their $1800-1840$ means and adjusting them to fit into our pentad scheme of plotting. There is apparently good correspondence prior to 1915 , but thereafter, the decline in the ice-core $\delta^{13} \mathrm{C}$ is much slower than the tree-ring chronology. The chronologies can be brought in line if either 1) the dating of the ice cores is off ca 35 years, or 2) there are factors, especially between 1915 and 1959, that have produced a faster decline in the pinyon curve. According to the Francey-Farquhar (1982) model of plant carbon isotope fractionation, such an effect could be produced through reduced carbon fixation and/or increased stomatal conductance. It is not clear what factor acting on a regional basis could cause this - the increasing $\mathrm{CO}_{2}$ concentration itself could be a possibility if it stimulates a condition in which the ratio of plant internal $\mathrm{CO}_{2}$ to atmospheric concentration increases. Some type of long-term climate influence is another possibility. The net drop in directly measured atmospheric $\delta^{13} \mathrm{C}$ between 1956 and 1982 appears to be greater by ca $0.1-0.2 \%$ than that in the pinyon chronology.

The second comparison is with other tree-ring isotope chronologies. The pinyon chronology shows substantially less of a $\delta^{13} \mathrm{C}$ decrease than the $1.8-2.0 \%$ drop from 1850-1980 found by Freyer and Belacy (1983). The pinyon chronology decreases slower than the Stuiver, Burk \& Quay (1984) chronology up to ca 1900, when the pinyon chronology decreases faster, although the overall drop in the Stuiver et al curve is ca 1.1\%o compared to the $1.2-1.4 \%$ of the pinyon. One interesting similarity, however, is that ca $1950-1960$ there is an upturn of $\delta^{13} \mathrm{C}$ values observed in all three chronologies. Another upturn of $\delta^{13} \mathrm{C}$ values at $1900-1910$ is common to the Stuiver et al and pinyon chronologies.

Finally, the change in $\delta^{13} \mathrm{C}$ of atmospheric $\mathrm{CO}_{2}$ from fossil-fuel contributions alone has been modeled by Peng et al (1983) and is shown as the dashed line in Figure 1d. The accompanying smoothed (by eye) pinyon curve would contain the influence of fossil fuels as well as biospheric contributions if it is representative of the atmosphere. The difference between the two (Fig 1e) then represents the biosphere input curve only. Although we have not done numerical modeling, comparison of this residual to the modeling results of Peng et al (1983) and Stuiver, Burk \& Quay (1984), suggest a cumulative biospheric $\mathrm{CO}_{2}$ input in excess of $140 \mathrm{Gt}$ carbon 
beginning in the late 1700 s and increasing to ca 1950 . Without modeling, however, we cannot estimate pre-industrial $\delta^{13} \mathrm{C}$ and $\mathrm{CO}_{2}$ values.

Drawing a smooth curve in Figure 1d assumes that the short-term $\delta^{13} \mathrm{C}$ variations in Figure $1 \mathrm{c}$ are unrelated to actual atmospheric $\delta^{13} \mathrm{C}$ changes. The modeling of Stuiver, Burk \& Quay (1984) suggests the fluctuation of $1 \%$ in the $\delta^{13} \mathrm{C}$ record translates to a change in atmospheric concentration of ca $40-50 \mathrm{ppm}$. If this is the case, the amplitude of pinyon $\delta^{13} \mathrm{C}$ fluctuations would equate to atmospheric $\mathrm{CO}_{2}$ variations of $12-15 \mathrm{ppm}$ over time scales of 5-20 yr. This seems excessive but some of the variations in $\delta^{13} \mathrm{C}$ of the ice cores are up to one-half of that magnitude.

\section{CONCLUSIONS}

The 14-site, 56-tree pinyon $\delta^{13} \mathrm{C}$ chronology presented herein is the most carefully developed and internally consistent currently available. The chronology decreases from the late 1700s to the present, moreso than the Stuiver et al chronology but much less than that of Freyer and Belacy (1983). The pinyon chronology generally shows lower $\delta^{13} \mathrm{C}$ values after 1850 than the $\delta^{13} \mathrm{C}$ directly measured on $\mathrm{CO}_{2}$ in ice cores and the atmosphere, and suggests a greater cumulative biospheric $\mathrm{CO}_{2}$ flux than modeled by Stuiver, Burk \& Quay (1984) from tree rings at $140 \mathrm{Gt}$ carbon and by Siegenthaler and Oeschger (1987) from ice cores of 90-150 Gt carbon. If the ice cores are providing accurate, well-dated values of past atmospheric $\delta^{13} \mathrm{C}$, then it is likely some physiological effects promoted by environmental changes (eg, $\mathrm{CO}_{2}$ concentration or climate) are causing the disparity in icecore and pinyon chronologies. At this time, however, we have not been able to isolate and quantify such an influence.

\section{ACKNOWLEDGMENTS}

We thank the US Department of Agriculture Ashley and Humboldt National Forests for permission to sample, and the Laboratory of Tree-Ring Research for dating the cores. S Cheng and L Warneke helped prepare and analyze samples. Sampling was supported by Subcontract No. 19X-22290C from Oak Ridge National Laboratory under Martin-Marietta Energy Systems, Inc contract with the US Department of Energy.

\section{REFERENCES}

Ezekiel, M and Fox, KA, 1959, Methods of correlation and regression analysis: New York, John Wiley \& Sons, Inc.

Francey, RJ and Farquhar, GD, 1982, An explanation of the ${ }^{13} \mathrm{C} / 12 \mathrm{C}$ variations in tree rings: Nature, v 297, p 28-31.

Freyer, HD and Belacy, N, $1983,{ }^{13} \mathrm{C} /{ }^{12} \mathrm{C}$ records in northern hemispheric trees during the past 500 years-anthropogenic impact and climatic superpositions: Jour Geophys Research, v 88, p $6844-6852$.

Friedli, H, Lötscher, H, Oeschger, H, Siegenthaler, U and Stauffer, B, 1986, Ice core record of the ${ }^{13} \mathrm{C} /{ }^{12} \mathrm{C}$ ratio of atmospheric $\mathrm{CO}_{2}$ in the past two centuries: Nature, $v$ 324, p 237-238.

Fritts, HC, 1976, Tree rings and climate: New York, Academic Press.

Keeling, CD, Bacastow, RB and Tans, PP, 1980, Predicted shift in the ${ }^{13} \mathrm{C} /{ }^{12} \mathrm{C}$ ratio of atmospheric carbon dioxide: Geophysical Research Letters, v 7, p 505-508.

Keeling, CD, Mook, WG and Tans, PP, 1979, Recent trends in the ${ }^{13} \mathrm{C} /{ }^{12} \mathrm{C}$ ratio of atmospheric carbon dioxide: Nature, v 277, p 121-123. 
Leavitt, SW and Long, A, 1985, The global biosphere as net $\mathrm{CO}_{2}$ source or sink: evidence from carbon isotopes in tree rings, in Caldwell, DE, Brierley, JA and Brierley, CL, eds, Planetary ecology: New York, Van Nostrand Reinhold, p 89-99.

1986, Trends of ${ }^{13} \mathrm{C} /{ }^{12} \mathrm{C}$ ratios in pinyon tree rings of the American Southwest and the global carbon cycle, in Stuiver, $\mathrm{M}$ and $\mathrm{Kra}, \mathrm{RS}$, eds, Internatl ${ }^{14} \mathrm{C}$ conf, $12 \mathrm{th}$, Proc: Radiocarbon, v 28, no $2 \mathrm{~A}$, p 376-382.

1988, Stable-carbon isotope chronologies from trees in the southwestern United States: Global Biogeochem Cycles, v 2, p 189-198.

Mook, WG, Koopmans, M, Carter, AF and Keeling, CD, 1983, Seasonal, latitudinal and secular variations in the abundance and isotopic ratios of atmospheric carbon dioxide 1. results from land stations: Jour Geophys Research, v 88, p 10915-10933.

Peng, TH, Broecker, WS, Freyer, HD and Trumbore, S, 1983, A deconvolution of the tree ring based $\delta^{13} \mathrm{C}$ record: Jour Geophys Research, v 88, p 3609-3620.

Siegenthaler, $\mathrm{U}$ and Oeschger, $\mathrm{H}, 1987$, Biospheric $\mathrm{CO}_{2}$ emissions during the past 200 years reconstructed by deconvolution of ice core data: Tellus, v 39B, p 140-154.

Stuiver, M, Burk, RL and Quay, $\mathrm{PD}, 1984,{ }^{13} \mathrm{C} /{ }^{12} \mathrm{C}$ ratios in tree rings and the transfer of biospheric carbon to the atmosphere: Jour Geophys Research, v 89, p 11731-11748. 